\title{
Analisis Kualitas Briket Serbuk Gergaji Kayu Dengan Penambahan Tempurung Kelapa Sebagai Bahan Bakar Alternatif
}

\author{
Asri Saleh, lin Novianty, Suci Murni, A. Nurrahma \\ Jurusan Kimia, Fakultas Sains dan Teknologi, UIN Alauddin Makassar \\ J. H.M. Yasin Limpo No. 36 Samata Gowa Sulawesi Selatan \\ Email: asri.dosen.uin@gmail.com
}

\begin{abstract}
Increasing fuel and liquid gas prices make this energy source is no longer cheap. Therefore, it is necessary to create an alternative energy resource that can be used to replace the role of fuel and gas. Waste sawdust and coconut shell has a huge potential that can be used as raw material charcoal briquettes. The purpose of this research is to improve the quality of sawdust briquettes with the addition of coconut shell charcoal. To improve the quality of charcoal briquettes, the addition of coconut shell charcoal with a variation of 20\%, 30\%, 40\%, 50\% and $60 \%$ of the weight of sawdust briquette charcoal. Authoring process is done by burning coconut shells directly and roasting methods to sawdust. Adhesives are used as much as 50\%. The calorific value generated in sawdust briquettes with materials: coconut shell at a concentration of $100 \%$ is $5622.7769 \mathrm{cal} / \mathrm{gram}$, a concentration of $80: 20 \%$ is $6504.67785 \mathrm{cal} / \mathrm{gram}$, the concentration of 70 : $30 \%$ is $6624.09305 \mathrm{cal} / \mathrm{gram}$, the concentration of $60: 40 \%$ is $7017.5178 \mathrm{cal} / \mathrm{gram}$, a concentration of 50: $50 \%$ is $7288.7523 \mathrm{cal} / \mathrm{gram}$ and $40: 60 \%$ is $7386.4805 \mathrm{cal} / \mathrm{gram}$. Overall, the quality of sawdust briquettes with palm shell charcoal is quite good, so it can be used as an alternative fuel
\end{abstract}

Keywords: briquettes, sawdust, coconut shell, bomb calorimeter

\section{PENDAHULUAN}

Sebagian besar energi yang digunakan masyarakat Indonesia saat ini berasal dari bahan bakar fosil yaitu bahan bakar minyak, batu bara dan gas. Penggunaan bahan bakar fosil ini memberikan dampak negatif yaitu dapat merusak lingkungan, tidak berkelanjutan dan tidak dapat diperbaharui. Sifat yang tidak dapat diperbaharui ini menyebabkan semakin menipisnya persediaan bahan bakar minyak, sehingga kita perlu memanfaatkan sumber energi alternatif baru yang dapat diperbaharui, ramah lingkungan dan dapat dijangkau oleh masyarakat menengah kebawah.

Kelangkaan bahan bakar minyak (BBM) khususnya minyak tanah dan LPG yang berimbas pada kenaikan harganya, memotifasi orang untuk berpikir mengenai energi alternatif pengganti bahan bakar minyak (BBM) yang lebih murah dan sumbernya mudah didapat. Disamping untuk mendapatkan sumber energi baru, juga harus berpikir untuk mengurangi emisi $\mathrm{CO}_{2}$ guna mencegah terjadinya pemanasan global telah mendorong penggunaan energi biomasa sebagai pengganti energi bahan bakar fosil seperti minyak bumi dan batu bara. Ketika seseorang selalu berpikir tentang apa yang diciptakan Allah SWT untuk manusia maka akan mengantarkannya 
pada berbagai solusi atas permasalahan-permasalahan yang ada. Sehingga pada akhirnya akan mengerti bahwa tidak ada satu hal pun yang diciptakan Allah SWT yang sia-sia.

Tempurung kelapa merupakan salah satu limbah yang banyak dan mempunyai potensi yang cukup melimpah, mudah diperoleh dengan harga yang relatif murah dan kebanyakan dibuang begitu saja oleh masyarakat sehingga menyebabkan pencemaran lingkungan. Oleh karena keberadaannya yang cukup melimpah sehingga dapat dimanfaatkan sebagai bahan bakar alternatif yang terbarukan yang memiliki nilai ekonomis yaitu dapat dicampurkan dengan serbuk gergaji kayu sebagai bahan dasar briket.

Briket merupakan perubahan bentuk material yang pada awalnya berupa serbuk atau bubuk seukuran pasir menjadi material yang lebih besar dan mudah dalam penanganan atau penggunaannya. Perubahan ukuran material tersebut dilakukan melalui proses penggumpalan dengan penekanan dan penambahan atau tanpa penambahan bahan pengikat.

Briket yang memiliki kualitas yang baik adalah briket yang memiliki kadar air, kadar abu, kadar zat terbang yang rendah, tetapi memiliki kerapatan, nilai kalor dan suhu api atau bara yang dihasilkan tinggi. Apabila briket dipergunakan di kalangan rumah tangga, maka hal yang penting diperhatikan adalah kadar zat terbang dan kadar abu yang rendah. Hal ini dikarenakan untuk mencegah polusi udara yang ditimbulkan dari asap pembakaran yang dihasilkan serta untuk memudahkan dalam penanganan ketika proses pembakaran selesai. Tujuan penelitian ini yaitu sebagai barikut:

1. Untuk mengetahui pengaruh penambahan tempurung kelapa terhadap peningkatan kualitas briket serbuk gergaji kayu

2. Untuk menentukan nilai kalor yang dihasilkan dari konsentrasi campuran serbuk gergaji kayu dan tempurung kelapa yang berbeda-beda

\section{METODE PENELITIAN}

\section{Alat}

Alat-alat yang digunakan adalah alat-alat gelas, bomb kalorimeter (parr), tanur (heracus furnace), oven (sharp), neraca analitik, desikator, cetakan briket, jangka sorong, cawan porselin, tabung pembakaran, panci dan baskom.

\section{Bahan}

Bahan-bahan yang digunakan adalah akuades $\left(\mathrm{H}_{2} \mathrm{O}\right)$, serbuk gergaji kayu, tempurung kelapa, perekat getah pinus, natrium karbonat dan indikator MO.

\section{Prosedur Kerja}

\section{a. Pembuatan Briket}

Serbuk gergaji dan arang tempurung kelapa yang telah halus dicampur kemudian dibuat briket pada beberapa komposisi bahan baku setelah terlebih dahulu dicampur dengan perekat getah pinus sebanyak 50\% dari berat bahan baku persatuan briket. Pembuatan briket ini dibedakan menjadi 6 kombinasi bahan baku:

1) $100 \%$ serbuk gergaji 
2) $80 \%$ serbuk gergaji dan $20 \%$ arang tempurung kelapa

3) $70 \%$ serbuk gergaji dan $30 \%$ arang tempurung kelapa

4) $60 \%$ serbuk gergaji dan $40 \%$ arang tempurung kelapa

5) $50 \%$ serbuk gergaji dan $50 \%$ arang tempurung kelapa

6) $40 \%$ serbuk gergaji dan $60 \%$ arang tempurung kelapa

Masing-masing komposisi bahan baku yang telah dibuat selanjutnya dimasukkan ke dalam alat cetak kemudian ditekan. Kemudian mengeluarkan hasil cetakan briket.Menyimpan briket yang sudah jadi pada tempatnya. Kemudian melakukan proses pengeringan sekitar 1-2 hari dibawah sinar matahari.

\section{b. Uji Kimia}

1. Kadar Air (Moisturase)

Cawan porselin yang telah bersih, dipanaskan dengan menggunakan oven pada suhu $105^{\circ} \mathrm{C}$ selama 1 jam, kemudian mengeringkan dalam desikator selama 1 jam, kemudian menimbang cawan tersebut (A gram). Menimbang briket sebanyak 1(cawan porselin + contoh $=\mathrm{B}$ gram). Memasukkan ke dalam oven pada suhu $105^{\circ} \mathrm{C}$ selama 1 jam, kemudian mendinginkan dalam desikator selama 1 jam lalu menimbang (cawan porselin + contoh $=\mathrm{C}$ gram).

\section{Kadar Abu (Ash)}

Cawan porselin yang telah bersih, dipanaskan dengan menggunakan oven dengan suhu $105^{\circ} \mathrm{C}$ selama $1 \mathrm{jam}$. Mengeringkan dalam desikator selama $1 \mathrm{jam}$, kemudian menimbang cawan tersebut (A gram). Menimbang briket sebanyak 1 gram (cawan porselin + contoh $=\mathrm{B}$ gram). Memasukkan ke dalam tanur pada suhu $650^{\circ} \mathrm{C}$ selama 2 jam, kemudian mendinginkan dalam desikator selama 2 jam lalu menimbang (cawan porselin + contoh $=\mathrm{C}$ gram).

\section{Kadar Zat Terbang (Volatil Matter)}

Cawan porselin yang telah bersih, dipanaskan dengan menggunakan oven pada suhu $105^{\circ} \mathrm{C}$ selama 30 menit.Mengeringkan dalam desikator selama 30 menit, kemudian menimbang cawan tersebut (A gram). Menimbang briket sebanyak 1 gram (cawan porselin + contoh $=\mathrm{B}$ gram). Memasukkan ke dalam tanur pada suhu $900^{\circ} \mathrm{C}$ selama 7 menit, kemudian mendinginkan dalam desikator selama 1 jam lalu menimbang (cawan porselin + contoh $=\mathrm{C}$ gram)

\section{Karbon Tetap (Fixed Carbon)}

Karbon tetap dihitung dari 100\% dikurangi dengan kadar air (moisturase) dikurangi kadar abu (ash) dikurangi kadar zat terbang (volatile matter).

\section{Nilai Kalor}

Dtimbang \pm 1 gram sampel ke dalam cawan besi. Kemudian disiapkan rangkaian alat bom kalorimeter, dipasang cawan ke rangkaian bom kalorimeter. Selanjutnya dihubungkan dengan kawat platina dan disentuhkan dengan sampel. Dimasukkan air sebanyak $1 \mathrm{~mL}$ ke dalam bejana bom kalorimeter, lalu dimasukkan rangkaian bom kalorimeter ke dalam bejana. Ditutup rapat lalu diisi dengan gas dengan tekanan 25-30 atm. Wadah bom kalorimeter diisi dengan $2 \mathrm{~L}$ air dan dimasukkan kedalam jaket bom kalorimeter. Kemudian dimasukkan ke dalam wadah bom kalorimeter kemudian ditutup. Suhu awal dan kenaikan suhu pada menit 5-10 dicatat Volume titran dicatat dan dihitung panjang kawat yang terbakar dan nilai kalor sampel. 


\section{c. Uji Fisika}

1. Kerapatan $(\rho)$

Peralatan yang digunakan termasuk benda uji ditimbang. Lalu diukur volume briket (volume silinder).

2. Kuat tekan

Briket diletakkan pada tumpuannya. Lalu dilakukan penyetelan jarum hitam dan merah pada monomer ke posisi 0 (nol), pengujian dimulai dengan mendorong handle penggerak motor ke depan. Briket dan jarum petunjuk pada manometer diperhatikan selama penekanan dilakukan, jika jarum hitam pada manometer tidak bergerak lagi maka beban maksimum tercapai dan pengujian telah selesai.

\section{HASIL DAN PEMBAHASAN}

\section{a. Uji Fisika}

1. Kerapatan

Kerapatan merupakan perbandingan antara berat dan volume briket arang. Besar kecilnya kerapatan dipengaruhi oleh ukuran dan kehomogengan arang penyusun briket arang tersebut. Nilai rata-rata kerapatan pada masing-masing komposisi perlakuan ditunjukkan pada gambar 3.1

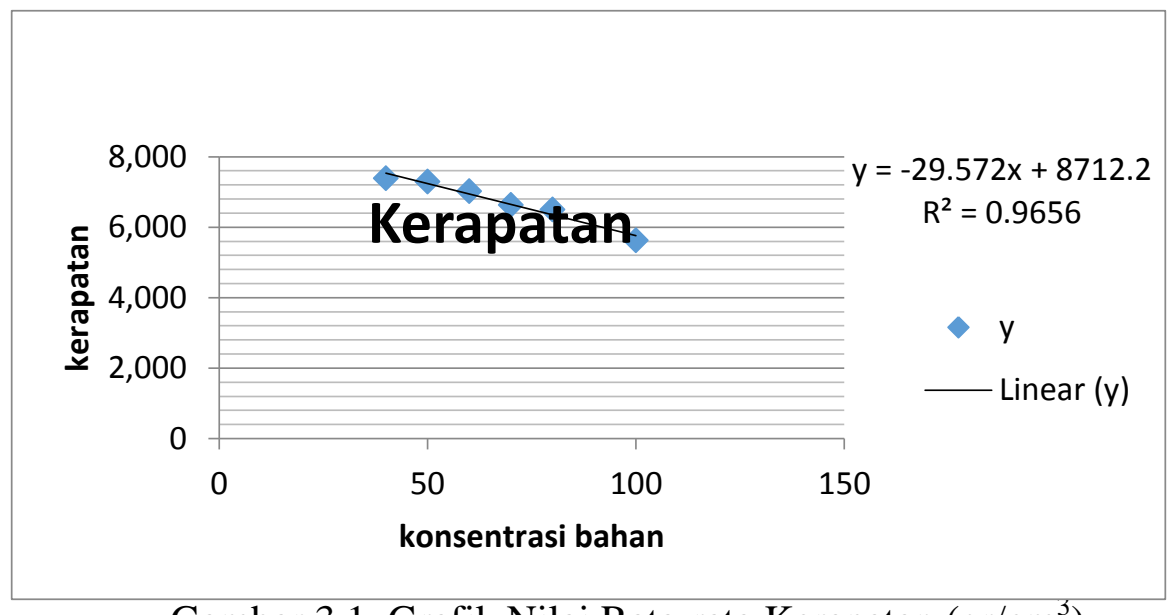

Gambar 3.1. Grafik Nilai Rata-rata Kerapatan $\left(\mathrm{gr} / \mathrm{cm}^{3}\right)$

Berdasarkan grafik diatas, kerapatan rata-rata yang diperoleh pada konsentrasi $100 \%$ adalah $0,535 \mathrm{gr} / \mathrm{cm}^{3}$, konsentrasi 80:20\% adalah $0,57 \mathrm{gr} / \mathrm{cm}^{3}$, konsentrasi $70: 30 \%$ adalah $0,59 \mathrm{gr} / \mathrm{cm}^{3}$, konsentrasi $60: 40$ adalah $0,62 \mathrm{gr} / \mathrm{cm}^{3}$, konsentrasi 50:50 adalah 0,63 gr/ $\mathrm{cm}^{3}$ dan konsentrasi 40:60\% adalah $0,66 \mathrm{gr} / \mathrm{cm}^{3}$. Hasil penelitian menunjukkan briket dengan perbandingan serbuk gergaji dan tempurung kelapa (40:60)\% mempunyai kerapatan lebih tinggi dibandingkan yang lain. Hal ini disebabkan karena massa campuran briket tempurung kelapa lebih tinggi dibandingkan dengan serbuk gergaji yang kurang kerapatannya.

Uji kerapatan briket merupakan sifat fisik briket yang berhubungan dengan kekuatan briket untuk menahan perubahan bentuk. Kerapatan berpengaruh terhadap tingkat energi yang 
terkandung dalam briket. Semakin tinggi kerapatan semakin tinggi pula energi yang terkandung dalam briket.

Menurut Erikson Sinurat (2011), semakin besar kerapatan bahan bakarmaka laju pembakaran akan semakin lama. Dengan demikian briket yang memiliki berat jenis yang besar memiliki laju pembakaran yang lebih lama dan nilai kalornya lebih tinggi dibandingkan dengan briket yang memiliki kerapatan yang lebih rendah, sehingga makin tinggi kerapatan briket semakin tinggi pula nilai kalor yang dihasilkan

\section{Uji Kuat Tekan}

Kuat tekan briket merupakan kemampuan briket untuk memberikan daya tahan atau kekompakan briket terhadap pecah atau hancurnya briket jika diberikan beban pada benda tersebut. Semakin tinggi nilai kuat tekan briket berarti daya tahan briket terhadap pecah semakin baik. Nilai rata-rata kuat tekan untuk masing-masing perlakuan ditunjukkan pada Gambar 4.2.

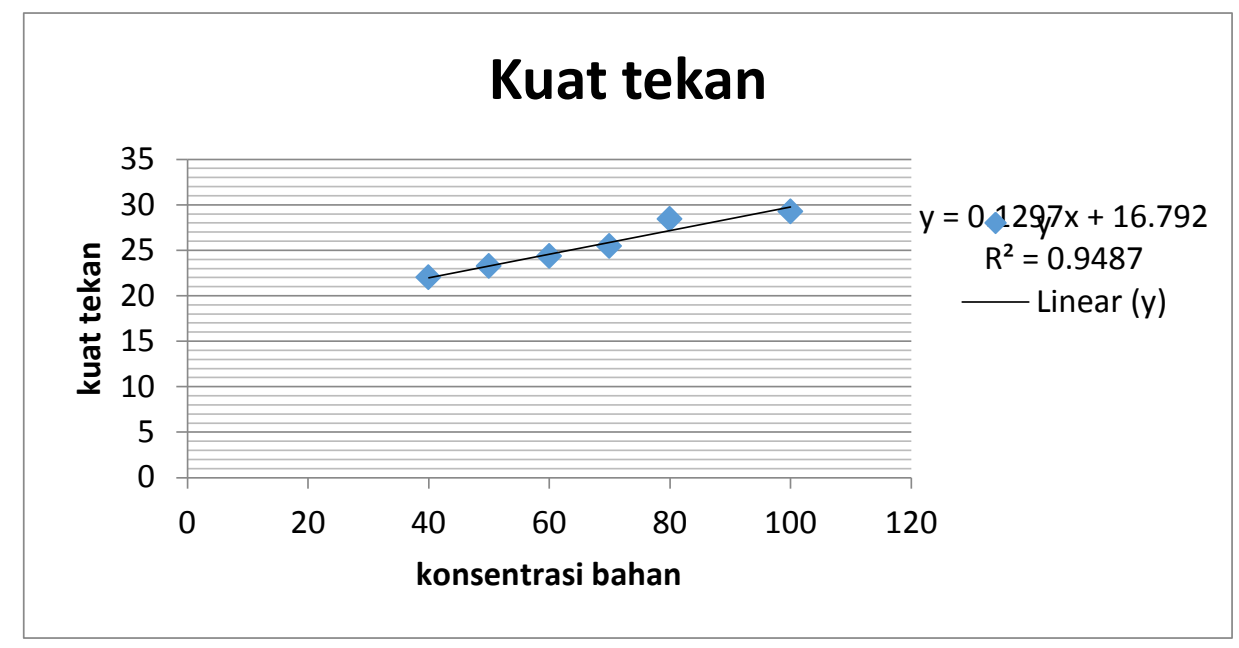

Gambar 3.2.Grafik Nilai Rata-rata Kuat Tekan.

Berdasarkan grafik diatas, kuat tekan rata-rata yang diperoleh pada konsentrasi $100 \%$ adalah $1,72 \mathrm{~g} / \mathrm{cm}^{3}$, konsentrasi $80: 20 \%$ adalah $1,98 \mathrm{~g} / \mathrm{cm}^{3}$, konsentrasi $70: 30 \%$ adalah 2,22 $\mathrm{g} / \mathrm{cm}^{3}$, konsentrasi $60: 40 \%$ adalah $3,13 \mathrm{~g} / \mathrm{cm}^{3}$, konsentrasi $50: 50 \%$ adalah $4,05 \mathrm{~g} / \mathrm{cm}^{3}$ dan konsentrasi 40:60\% adalah $4,15 \mathrm{~g} / \mathrm{cm}^{3}$. Nilai kuat tekan tertinggi pada konsentrasi bahan 40:60\% dan terendah pada konsentrasi $100 \%$. Pada grafik tampak jelas bahwa penambahan tempurung kelapa pada briket serbuk gergaji mempengaruhi kualitas briket yang dihasilkan.

\section{b. Uji Kimia}

1. Kadar air

Kadar air briket berpengaruh terhadap nilai kalor. Semakin kecil nilai kadar air maka semakin bagus nilai kalornya. Briket arang mempunyai sifat higroskopis yang tinggi. Sehingga perhitungan kadar air bertujuan untuk mengetahui sifat higroskopis briket arang hasil penelitian. Nilai rata-rata kuat tekan pada masing-masing komposisi perlakuan ditunjukkan pada gambar 3.3 . 


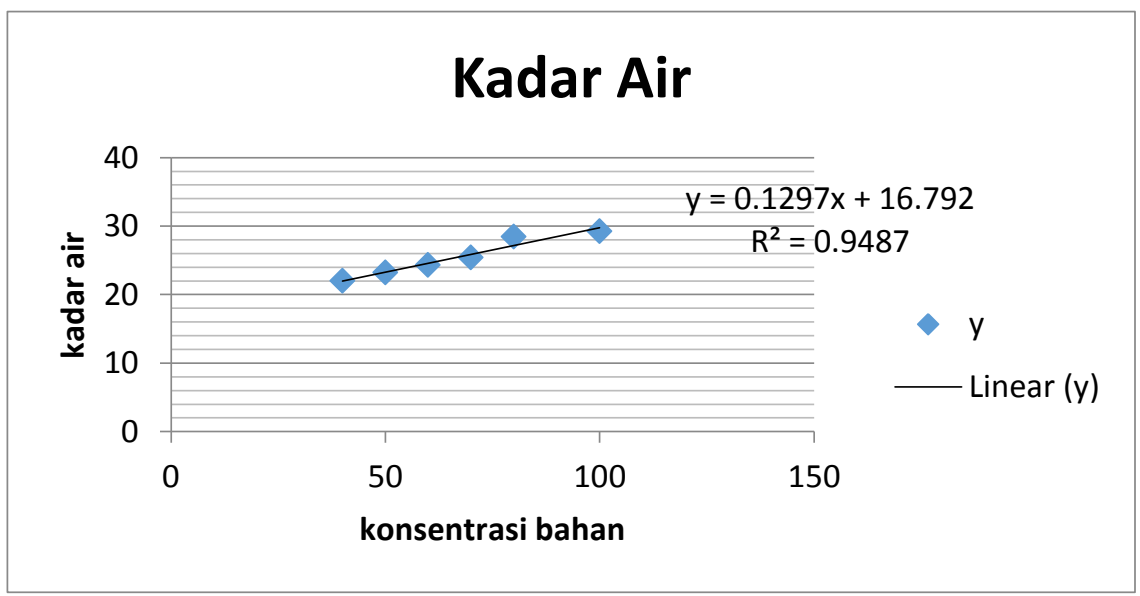

Gambar 3.3. Grafik Nilai Rata-rata Kadar Air

Berdasarkan grafik diatas, kadar air rata-rata yang diperoleh pada konsentrasi $100 \%$ adalah $8,89 \%$, konsentrasi $80: 20 \%$ adalah $6,16 \%$, konsentrasi $70: 30 \%$ adalah $4,94 \%$, konsentrasi 60:40\% adalah 4,71\%, konsentrasi 50:50\% adalah 4,33, dan konsentrasi 40:60\% adalah 3,87\%. Hasil penelitian menunjukkan briket konsentrasi 100\% mempunyai kadar air paling tinggi, hal ini disebabkan karena serbuk gergaji kayu yang digunakan memiliki jumlah pori yang masih cukup banyak dan mampu menyerap air, hal ini sesuai dengan teori Triono (2011) tingginya kadar air pada serbuk gergaji kayu disebabkan karena serbuk gergaji kayu memiliki jumlah poripori yang lebih banyak.

Nilai rata-rata kadar air pada setiap perlakuan masih dibawah standar SNI yaitu 8\%. Hal ini berarti bahwa nilai kadar air memenuhi standar SNI.

2. Kadar abu

Abu merupakan bagian yang tersisa dari hasil pembakaran dalam hal ini adalah sisa pembakaran briket arang.Salah satu unsur penyusun abu adalah silika, pengaruhnya kurang baik terhadap nilai kalor briket yang dihasilkan.Kandungan abu yang tinggi dapat menurunkan nilai kalor briket arang sehingga kualitas briket arang tersebut menurun. Nilai rata-rata kadar abu pada setiap perlakuan ditunjukkan pada gambar 3.4.

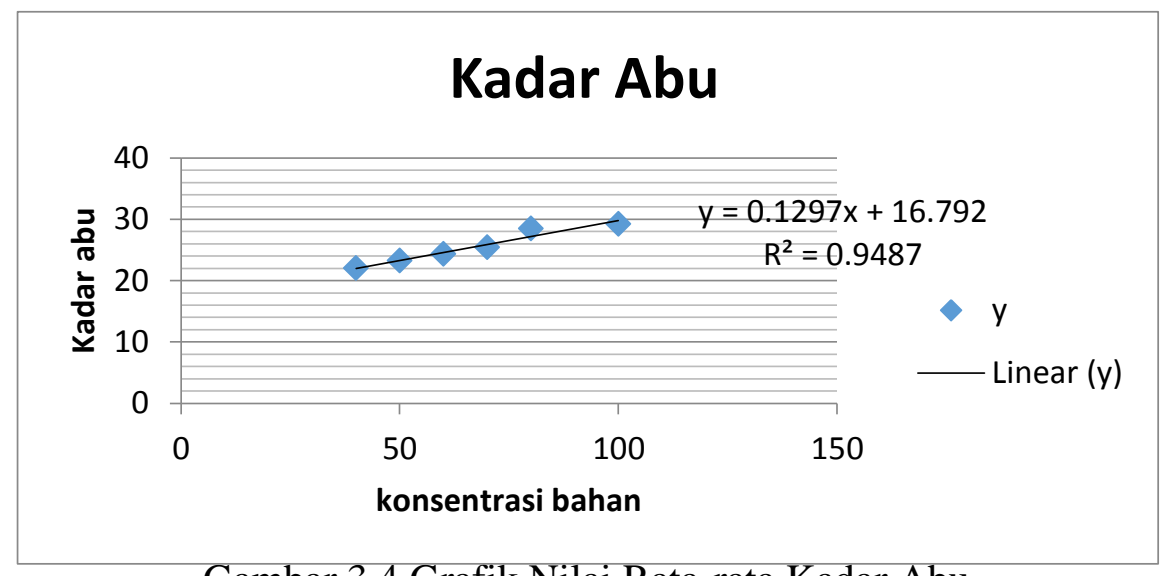

Gambar 3.4.Grafik Nilai Rata-rata Kadar Abu 
Berdasarkan grafik diatas, kadar abu rata-rata pada konsentrasi $100 \%$ adalah 1,36\%, konsentrasi $80: 20 \%$ adalah $1,255 \%$, konsentrasi $70: 30 \%$ adalah 1,135\%, konsentrasi $60: 40 \%$ adalah $0,93 \%$, konsentrasi 50:50\% adalah 0,785\%, dan konsentrasi 40:60\% adalah 0,61\%.Hasil penelitian menunjukkan bahwa pada briket campuran serbuk gergaji dan tempurung kelapa dengan konsentrasi $100 \%$ memiliki kadar abu yang paling tinggi sedangkan pada konsentrasi 40:60\% memiliki kadar abu paling rendah, ini disebabkan karena bahan baku serbuk gergaji lebih udah terbakar daripada tempurung kelapa.

Menurut Hendra dan Darmawan (2000), kandungan abu yang tinggi berpengaruh kurang baik terhadap nilai kalor yang dihasilkan, semakin rendah kadar abu maka semakin baik kualitas briket yang dihasilkan. Hasil uji kadar abu yang dihasilkan memenuhi standar briket yang ditentukan yaitu 8-10\%. Penentuan kadar abu pada briket merupakan uji kimia, kadar abu yang terkandung dalam briket berpengaruh terhadap kualitas briket yang dihasilkan, dimana semakin besar kandungan abu pada briket maka semakin rendah kalor dan daya pembakaran yang dihasilkan.

3. Kadar zat terbang

Zat terbang (volatile matter) adalah zat yang dapat menguap sebagai hasil dekomposisi senyawa-senyawa yang masih terdapat dalam arang selain air. Nilai rata-rata kadar zat terbang pada setiap perlakuan ditunjukkan pada gambar 3.5 .

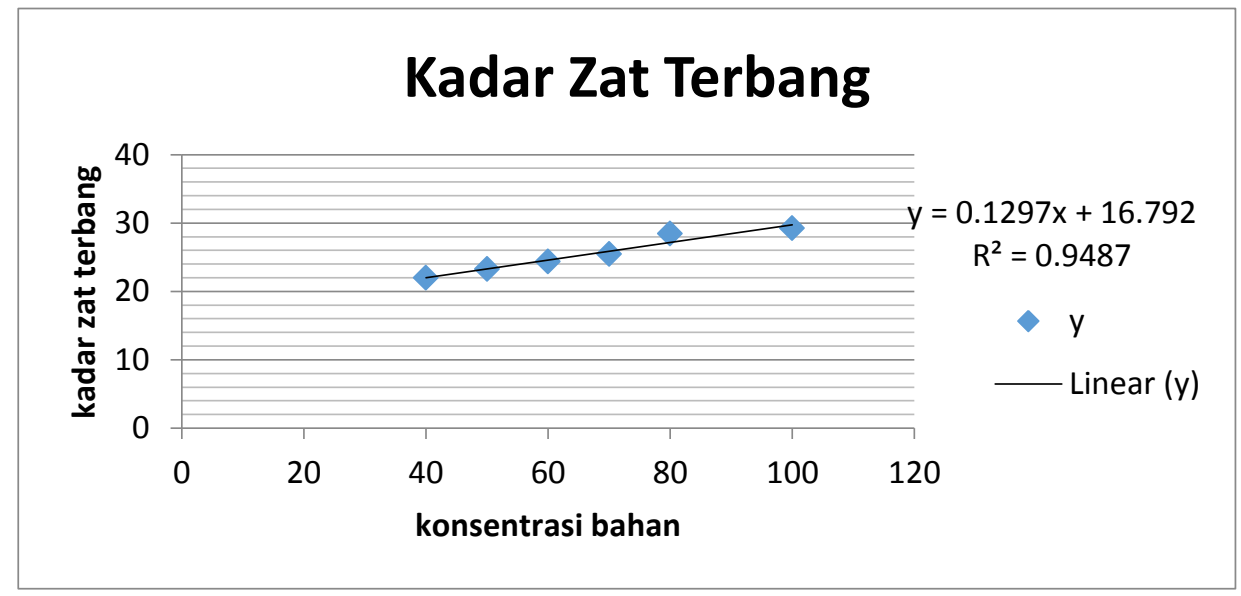

Gambar 3.5. Grafik Nilai Rata-rata Kadar Zat Terbang

Berdasarkan grafik diatas, kadar zat terbang rata-rata pada konsentrasi $100 \%$ adalah $29,24 \%$, konsentrasi $80: 20 \%$ adalah $28,43 \%$, konsentrasi $70: 30 \%$ adalah $25,42 \%$, konsentrasi $60: 40 \%$ adalah 24,34\%, konsentrasi 50:50\% adalah 23,24\%, dan konsentrasi 40:60\% adalah 21,985\%.

Kandungan zat terbang pada briket campuran serbuk gergaji dan tempurung kelapa melebihi standar briket batu bara yang ada, dimana kandungan zat terbang yang sesuai standar sebesar $15 \%$. Tingginya kadar zat terbang briket dikarenakan kadar minyak dalam briket masih cukup tinggi terutama kadar minyak pada tempurung kelapa. Kadar zat terbang yang terlalu tinggi menurunkan kualitas briket karena banyaknya zat terbang maka kandungan karbon semakin kecil sehingga nilai kalor yang dihasilkan semakin rendah. 
4. Karbon tetap

Karbon tetap merupakan salah satu parameter yang digunakan untuk menetukan kualitas briket, dimana semakin tinggi kadar karbon tetap maka semakin baik pula kualitas briket yang dihasilkan karena kadar karbon tetap yang tinggi akan menghasilkan briket yang minim asap pada saat pembakaran.Nilai rata-rata karbon tetap pada setiap perlakuan ditunjukkan pada gambar 3.6.

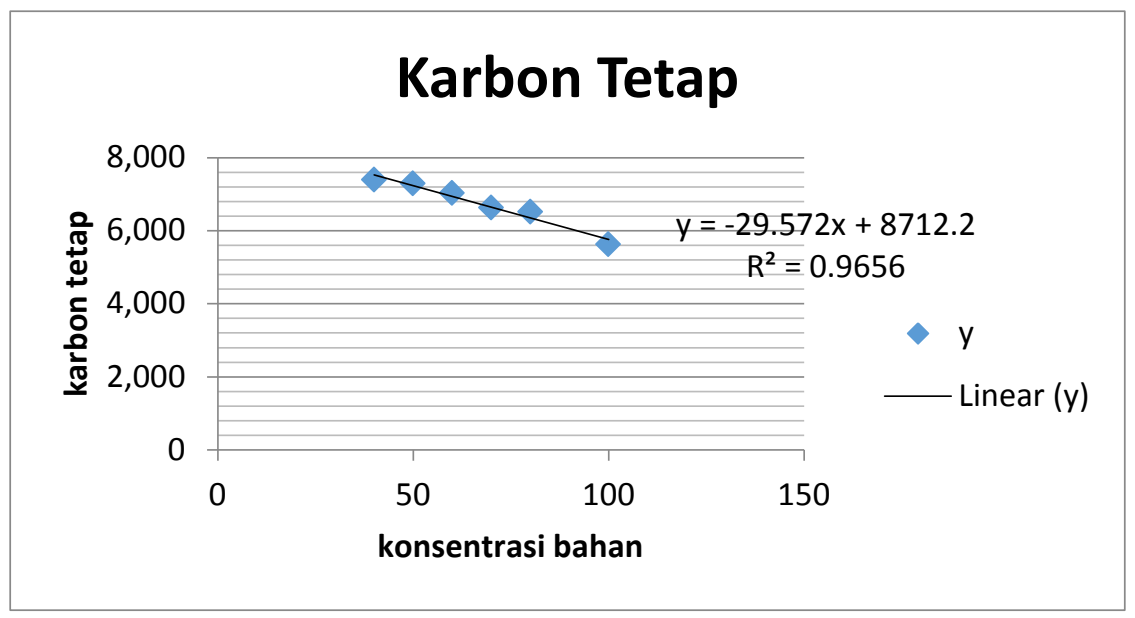

Gambar 3.6 Grafik Nilai Rata-rata Karbon Tetap

Berdasarkan grafik diatas, kadar karbon tetap rata-rata pada konsentrasi $100 \%$ adalah 1,72 $\mathrm{kg} / \mathrm{cm}^{2}$, konsentrasi $80: 20 \%$ adalah $1,98 \mathrm{~kg} / \mathrm{cm}^{2}$, konsentrasi $70: 30 \%$ adalah $2,225 \mathrm{~kg} / \mathrm{cm}^{2}$, konsentrasi $60: 40 \%$ adalah $3,13 \mathrm{~kg} / \mathrm{cm}^{2}$, konsentrasi $50: 50 \%$ adalah $4,05 \mathrm{~kg} / \mathrm{cm}^{2}$, dan konsentrasi 40:60\% adalah $4,155 \mathrm{~kg} / \mathrm{cm}^{2}$.

Menurut Diah Sundari Wijayanti (2009), keberadaan karbon tetap dalam briket dipengaruhi oleh nilai kadar zat terbang. Hasil penelitian menunjukkan semakin tinggi kadar karbon tetap makasemakin tinggi kalor yang dihasilkan. Keberadaan karbon tetap dalam briket dipengaruhi oleh nilai kadar zat terbang, kadar karbon tetap bernilai tinggi jika zat terbang berkurang.

\section{Nilai Kalor}

Nilai kalor sangat menentukan kualitas briket arang.Semakin tinggi nilai kalor briket arang, semakin baik pula kualitas briket arang yang dihasilkan. Menurut nurhayati (2008) nilai kalor dipengaruhi oleh kadar air dan kadar abu briket arang. Semakin tinggi kadar air dan kadar abu maka akan menurunkan nilai kalor briket arang yang dihasilkan. Nilai rata-rata kalor dari setiap perlakuan ditunjukkan pada gambar 3.7. 


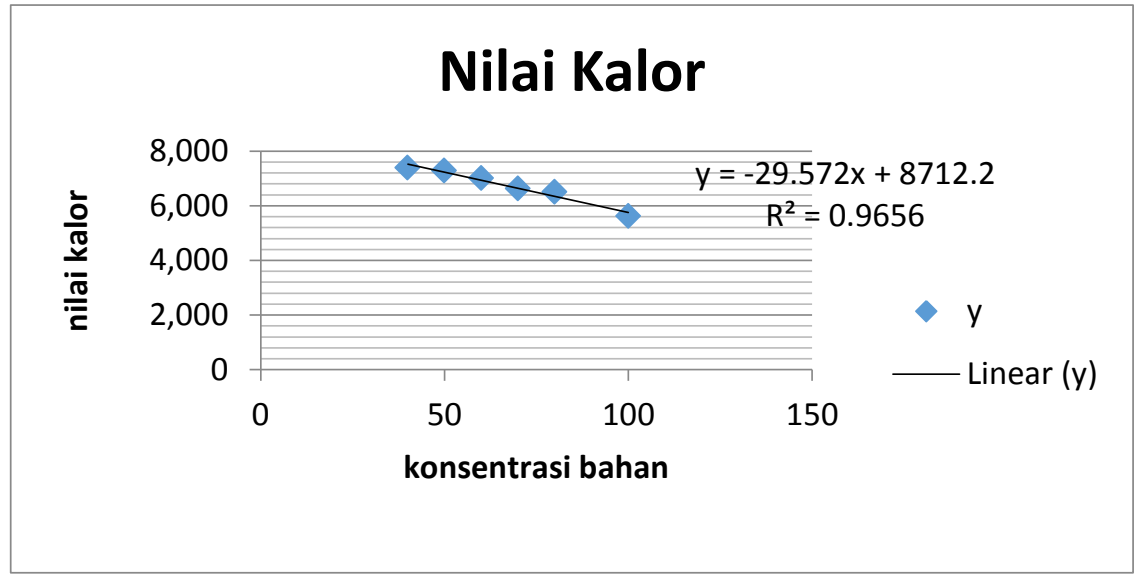

Gambar 3.7. Grafik Nilai Rata-rata Nilai Kalor

Berdasarkan grafik diatas, nilai kalor rata-rata pada konsentrasi $100 \%$ adalah 5622,77, konsentrasi 80:20\% adalah 6504,67, konsentrasi 70:30\% adalah 6624,093, konsentrasi 60:40\% adalah 7017,51, konsentrasi 50:50\% adalah 7288,75 adalah, dan konsentrasi 40:60\% adalah 7386,48 .

Hasil penelitian menunjukkan briket pada konsentrasi 40:60\% mempunyai nilai kalor paling tinggi dibandingkan yang lain, sedangkan nilai kalor terendah terdapat pada konsentrasi $100 \%$ serbuk gergaji kayu.

Penambahan tempurung kelapa mampu meningkatkan kualitas briket arang serbuk gergaji kayu yang dihasilkan.Peningkatan nilai kalor pada briket yang dihasilkan menunjukkan bahwa arang tempurung kelapa memang memiliki nilai kalor yang tinggi.Ditinjau dari segi nilai kalor, briket campuran serbuk gergaji dengan tempurung kelapa telah memenuhi Standar Nasional Indonesia (SNI) yaitu minimal 5600 kalori/gram.

Penelitian ini berakhir pada konsentrasi perbandingan serbuk gergaji kayu dan tempurung kelapa (40:60) karena sudah mewakili hasil bahwa tempurung kelapa memang memiliki nilai kalor yang tinggi, karena apabila dilanjutkan dengan konsentrasi serbuk gergaji kayu dan tempurung kelapa (20:80)\% maka nilai kalornya akan tetap lebih tinggi. Menurut Geonadi et al (2005) menyatakan bahwa nilai kalor dari briket arang tempurung kelapa yaitu sebesar 6600 kal/gram. Ditinjau dari segi nilai kalor, briket dari arang tempurung kelapa tersebut telah memenuhi Standar Nasional Indonesi (SNI) untuk briket arang kayu yaitu sebesar 5000 kal/gram, maka semakin bertambah arang tempurung kelapa maka semakin tinggi pula nilai kalor yang dihasilkan sesuai pertambahan komposisinya.

\section{PENUTUP}

\section{Kesimpulan}

Penambahan tempurung kelapa mampu meningkatkan kualitas briket arang serbuk gergaji kayu yang dihasilkan. 
Nilai kalor terendah dihasilkan pada briket dengan bahan serbuk gergaji $100 \%$ tanpa penambahan tempurung kelapa yaitu $5622,77 \mathrm{kal} /$ gram dan nilai kalor tertinggi terdapat pada konsentrasi campuran serbuk gergaji kayu dan tempurung kelapa (40:60)\% yaitu 7386,48 $\mathrm{kal} /$ gram.

\section{DAFTAR PUSTAKA}

Ari Setio Wibowo, 2009, Kajian Pengaruh Komposisi Dan Perekat Pada Pembuatan Briket Sekem Padi Terhadap Kalor Yang Dihasilkan, http://eprints.undip.ac.id/8513/1.pdf. Diakses 4 Maret 2014.

Atkins, P.W. 1990, Kimia Fisika. Jakarta : Erlangga.

Budi, Esmar dan Hadi, 2011, Nasbey Pemanfaatan Briket Arang Tempurung Kelapa sebagai Bahan Bakar Pengganti, Spektra: Jurnal Fisika dan Aplikasinya, 12(2): 26.

Fachri, A.Rasyid, 2010, Mencari Suhu Optimal Proses Karbonisasi dan Pengaruh Campuran Batubara Terhadap Kualitas Briket Eceng Gondok. Journal of Mechanical Engineering Learning, 17(2): 5-6

Ismayana, Andes dan Moh. Rizal Afriyanto, Pengaruh jenis dan Kadar Bahan Perekat pada Pembuatan Briket Blotong Sebagai Bahan Bakar Alternatif, J. Tek. Ind. Pert., 21 (187).

Lukum Haris, Ishak Isa danMangara Sihaloho, 2012. Pemanfaatan Arang riket Limbah Tongkol Jagung Sebagai Bahan Bakar Alternatif, Jurnal Sainstek, 6 (5): 1- 3 